REFLECTIONS:

NEUROLOGY AND

THE HUMANITIES

Section Editor

Anne W. McCammon,

MD, FAAN

Glenn R. Wylie, DPhil

Correspondence \& reprint requests to Dr. Wylie: gwylie@kesslerfoundation.org

\section{The Grand Old Man}

Of course, Grant still loved the old man. It was becoming increasingly difficult, but for Grant's entire adult life old Nat had been such a part of every action Grant took, every thought, that to strike out on his own, without the backing of the renowned Nat I. Health, was nearly unthinkable. Yet Grant had little choice. The old man was becoming increasingly peculiar, even as he became increasingly impecunious.

It hadn't always been this way. Perhaps a decade ago, the old man had been Grant's staunchest friend, supporting him in any way he could. Grant was a young man then and had taken this support, naively, as his due. He had not supposed that things could be otherwise: Grant's ideas were good, and the old man stood behind him. It seemed to make perfect sense.

But then the hard times came, and the old man began to retreat. He seemed to age suddenly and dramatically. Whereas before he had been an institution, now he seemed more like a captious old man on a modest fixed income. Speaking with him on the phone, Grant imagined that the old man's roof had begun to leak and that his cardigans were threadbare at the elbows. The old man withdrew not just from Grant but from nearly all of his former associates.

It was sad, and for Grant it was surprising, too. He knew that age was inevitable and senility probable, but he had truly thought that the old man was proof against such things. He had believed that the old man was exempt, probably because the old man had played a large role not only in Grant's life but also in the lives of his whole family. Generations of Grants had called old Nat their friend, and the old man had nurtured them and helped them to thrive.

But now the old man seemed to be pulling away. When Grant went to speak with him, the old man would cut him off before he could finish and then complain that Grant hadn't explained himself sufficiently to be understood. He had also decided that
Grant could repeat himself only once: after that, the conversation was over, regardless of the outcome. On one level, Grant understood this. The old man was very busy and had limited time to allocate his increasingly limited resources. But on another level, Grant chafed at the old man's querulousness, and worried that this was another sign of encroaching senility or, at least, decline.

If it had just been Grant that would have been bad enough, but many of the old man's associates said the same thing. They clucked their tongues and shook their heads and wondered what would become of the old man's interests. For his part, the old man fiercely proclaimed that his interests would not suffer (even as he sadly lamented his increasing insolvency), but it was clear that they must. Grant himself had to go looking for other support, other backing.

Perhaps this was the old man's plan all along: to get those who could find other support to do so. Detractors had said for years that he was too indulgent. But it didn't feel like a plan: it felt like the maladroit grasping of a failing old man who was trying to maintain his influence despite his physical, mental, and financial frailty, but whose efforts were making him increasingly irrelevant.

That was Grant's worst fear. Not that the old man would finally turn him out, not that he'd never get another encouraging letter with old man's spare signature "N.I.H." at the bottom, but that the old man would lose his place in the world. That he'd be overtaken by rivals who he had helped and encouraged in years past. That he would no longer be a player in the advancement of knowledge and science and medicine, but instead would sit at home before a fire, with a shawl over his legs against the chill, while the house that he'd built with such care and skill in his better days fell into decay and ruin around him. 


\title{
Neurology
}

\author{
The Grand Old Man \\ Glenn R. Wylie \\ Neurology 2012;79; 77
}

DOI 10.1212/WNL.0b013e318266fd01

This information is current as of August 27, 2012

\section{Updated Information \&}

Services

Permissions \& Licensing

Reprints including high resolution figures, can be found at: http://n.neurology.org/content/79/9/e77.full

Information about reproducing this article in parts (figures,tables) or in its entirety can be found online at:

http://www.neurology.org/about/about_the_journal\#permissions

Information about ordering reprints can be found online:

http://n.neurology.org/subscribers/advertise

Neurology ${ }^{\circledR}$ is the official journal of the American Academy of Neurology. Published continuously since 1951, it is now a weekly with 48 issues per year. Copyright Copyright (? 2012 by AAN Enterprises, Inc.. All rights reserved. Print ISSN: 0028-3878. Online ISSN: 1526-632X.

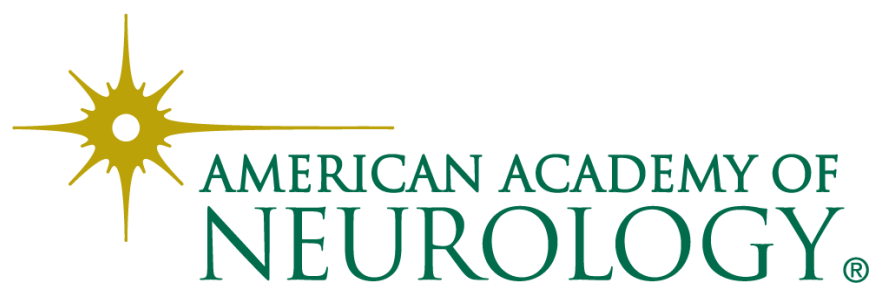

